\title{
STUDIES IN KERNICTERUS. I. THE PROTEIN BINDING OF BILIRUBIN *
}

\author{
BY GERARD B. ODELL \\ (From the Harriet Lane Home of The Johns Hopkins Hospital and from the Departments of \\ Pediatrics, Johns Hopkins University School of Medicine and Sinai Hospital of \\ Baltimore, Baltimore, Md.)
}

(Submitted for publication October 14, 1958; accepted January 15, 1959)

The yellow staining of basal ganglia (kernicterus) in some jaundiced newborn infants has been recognized for many years (1). The association between serum bilirubin concentration and kernicterus $(2,3)$, the isolation of bilirubin from kernicteric brains $(4,5)$, and the toxic effect of bilirubin in vitro upon oxygen uptake (6) and oxidative phosphorylation (7) are further evidence of a relationship between bilirubinemia and kernicterus. Plasma concentrations of bilirubin exceeding $20 \mathrm{mg}$. per cent are considered levels above which kernicterus occurs, although many exceptions exist $(8,9)$, particularly in the premature infant (10). Of particular importance was the observation (11) that kernicterus occurred more frequently in premature infants given sulfisoxazole than in control infants despite lower plasma bilirubin concentrations (12). Animal studies have confirmed these findings (13). Because kernicterus can occur at bilirubin concentrations considerably below $20 \mathrm{mg}$. per cent and fail to occur at higher concentrations, a study of factors controlling distribution of bilirubin seemed indicated. ${ }^{1}$

The binding of bilirubin to serum proteins has been demonstrated by many techniques (14-20). In vitro separation of bilirubin by ultrafiltration from serum protein in detectable amounts has been singularly unsuccessful (20-25). Bilirubin did not appear in ultrafiltrates of plasma unless the concentrations were greater than $80 \mathrm{mg}$. per cent $(22,25)$. However, bilirubin gains access to cell cytoplasm at considerably lower concentrations in vivo, and probably has to dissociate from

* These studies have been supported by a grant (H2727) from The National Heart Institute of the National Institute of Health, United States Public Health Service, and gifts from the Pierce Butler Fund for the Study of the Etiology of Cerebral Palsy and Related Disorders.

1 Suggested to the author by Dr. R. E. Cooke. serum protein in order to diffuse through cell membranes.

The study of protein-binding of bilirubin by various techniques has led to different interpretations as to which of the serum proteins are primarily involved in the in vivo transport of this pigment $(17,25,26)$. Alpha 1-globulin, $\alpha 2$-globulin, iron-binding globulin and $\beta$-globulin have all been demonstrated capable of binding bilirubin. All studies are in agreement that serum albumin is concerned in the binding of bilirubin but there is disagreement that albumin binds unconjugated bilirubin (26). Alpha 1-globulin has been shown to bind more unconjugated bilirubin on a weight basis than albumin, but serum contains so little of this component that the amount of bilirubin bound by $\alpha_{1}$-globulin is small compared to the total bound bilirubin in very icteric sera $(19,25)$.

The affinity of albumin for many organic anions is well known and can often be expressed stoichiometrically (27). Methods have been developed for quantitative and qualitative determination of albumin in serum based on this property (28-31). However, many of these methods gave erroneously low results in the presence of bilirubinemia. These latter observations demonstrated that bilirubin would interfere with organic anion binding of serum albumin, presumably by competition for the same loci (29).

The present study reports observations of the effects on the protein binding of bilirubin of certain organic anions some of which are used in clinical medicine. A preliminary report of these studies has been previously presented (32).

\section{METHODS}

Sera from 20 newborn infants with high bilirubin concentrations ranging from 10 to $28 \mathrm{mg}$. per cent were collected and, if not immediately used, were kept refrigerated at $4^{\circ} \mathrm{C}$. The causes of the bilirubinemia were erythro- 
blastosis or nonhemolytic hyperbilirubinemia of unknown cause. The sera used contained less than $2 \mathrm{mg}$. per cent direct reacting bilirubin.

A model serum was employed using dilutions of bovine albumin ${ }^{2}$ in a $0.1 \mathrm{M}$ phosphate buffer, $\mathrm{pH}$ 7.4. To the diluted albumin solutions, various amounts of aqueous bilirubin were added. The bilirubin solution was made by dissolving crystalline bilirubin (Hoffman-La Roche) in deaerated N/20 sodium hydroxide containing ascorbic acid. The model sera were freshly made on the day of use.

Spectrophotometric studies. Aqueous bilirubin is known to have an absorption maximum between 420 and $440 \mathrm{~m} \mu$, and protein-bound bilirubin in aqueous solutions has an absorption maximum in the vicinity of $460 \mathrm{~m} \mu$. The molecular extinction coefficients of the two forms of bilirubin are similar and their solutions obey Beer's Law $(15,19,25)$.

In the present experiments the effects of organic anions were studied by observing the changes in spectral absorption of bilirubinemic sera or model sera with a Beckman DU model spectrophotometer. The sera from the patients were diluted 20 - or 50 -fold with water or $0.1 \mathrm{M}$ phosphate buffer, pH 7.4. Equal volumes were pipetted into each of three $1 \mathrm{~cm}$. corex cuvettes. Water was used as a blank. The spectral absorption of the samples was measured between 400 and $500 \mathrm{~m} \mu$ and the wave length at which maximum absorption occurred in the $460 \mathrm{~m} \mu$ range was considered that due to protein-bound bilirubin. Subsequently equal volumes of various organic anions in concentrated solutions were pipetted into two of the cuvette samples. A control consisted of an equal dilution of the third sample with water or the phosphate buffer. The additions were made serially with calibrated 20 lambda washout pipettes. The optical density of each solution was measured at the original $460 \mathrm{~m} \mu$ maximum for the serum after each addition of organic anion or diluent. The spectral curves between 400 and $500 \mathrm{~m} \mu$ were repeated after the final additions. Decrease in absorption after anion addition greater than that which occurred in the control samples was considered as an indication of uncoupling of bilirubin from protein. The changes in optical density were expressed as percentage changes from the control sample:

$$
\% \Delta \text { O.D. } 460 \max .=\frac{\epsilon_{\mathrm{c}}-\epsilon_{\mathrm{a}}}{\epsilon_{\mathrm{c}}} \times 100 .
$$

$\epsilon_{\mathrm{c}}$ and $\epsilon_{\mathrm{a}}$ are, respectively the optical densities at the absorption maximum of the control sample and the sample to which anion had been added. The contribution of the uncoupled bilirubin to the total absorption at the $460 \mathrm{~m} \mu$ maximum was not subtracted. Consequently the per cent $\Delta$ O.D. represents a minimum value for the uncoupling of protein-bound bilirubin. The $\mathrm{pH}$ of the serum samples was measured with a Beckman model

2 Armour and Company, prepared by the cold decanol fractionation procedure of Cohn. Purchased as a 30 per cent aqueous solution.
$\mathrm{G} \mathrm{pH}$ meter before and after anion additions in 10 instances: five when water was used as the diluent and five when the phosphate buffer was used. No fall in $\mathrm{pH}$ occurred except where mentioned in the results.

Total bilirubin concentrations were measured on the cuvette samples by the Malloy and Evelyn modification of the van den Bergh reaction (33) in the 10 instances where the samples were diluted with water. A Bausch and Lomb Spectronic 20 colorimeter adapted for $1 \mathrm{~cm}$. corex cells was employed.

The concentration of the protein in the bovine albumin model sera was 60 to $240 \mathrm{mg}$. per cent and was determined from the dilution of the known 30 per cent stock solution. The protein concentrations were not determined in the patient's sera.

Changes in optical density of 0.002 unit were considered significant after individual anion additions when the optical density of the sample was between 0.1 and 0.5 and 0.005 unit when between 0.5 and 1.0.

Bilirubin values determined by the van den Bergh reaction in this laboratory have a 3 per cent error in bilirubin concentrations of $10 \mathrm{mg}$. per cent or more and a 4 to 5 per cent error in the 5 to $10 \mathrm{mg}$. per cent range.

Other spectrophotometric analyses were done by quantitative dilution of serum aliquots in calibrated volumetric flasks. The diluent was either distilled water or phosphate-buffer containing various concentrations of organic anions. The spectral analyses were done immediately after dilution or deliberately delayed for various intervals.

The organic anions used were sulfisoxazole diethanolamine (Hoffman La Roche, Inc.); U. S. P. sodium sulfadiazine (Abbott \& Co.); sodium salicylate (Baker Chemical Co.); heparin sodium, $10 \mathrm{mg}$. per $1 \mathrm{ml}$. (The Upjohn Co.) ; sulfanilic acid (Merck); glucuronic acid (California Foundation for Biochemical Research); and sodium glucuronate (California Foundation for Biochemical Research).

Ultrafiltration studies. Ultrafiltrations of whole or diluted human and model sera were done by centrifugation at room temperature of sera contained in a dialysis bag suspended in a centrifuge tube.

Various volumes of concentrated sodium salicylate, sodium sulfadiazine, sulfisoxazole and sulfanilic acid were added to the sera to yield concentrations of 5 to $25 \mathrm{mg}$. per cent before ultrafiltration. A control consisted of a simultaneous ultrafiltration of a serum sample diluted with water equal to the volume of added organic anion solution. Ultrafiltrations were also done with serum samples containing added glucuronic acid and sodium glucuronate in concentrations of 20,50 and $200 \mathrm{mg}$. per cent. The ultrafiltration of serum by centrifugation required 10 to 30 minutes.

The qualitative analysis of the ultrafiltrates for bilirubin was done spectrophotometrically and colorimetrically by the van den Bergh reaction. The ultrafiltrates obtained from the centrifugation of the model sera were extracted with chloroform, and the chloroform layer was tested for bilirubin qualitatively as above. The ultrafiltrates were tested for protein qualitatively by the 
presence of a precipitate after addition of 10 per cent tricloracetic acid.

Dialysis studies. Jaundiced human sera were prepared as in the ultrafiltration studies and dialyzed in cellulose casings against running cold water, protected from light, for 5 to 72 hours. The samples were subsequently analyzed for the remaining bilirubin. These experiments were done using either the undiluted sera or samples diluted with water.

\section{RESULTS}

\section{Spectrophotometric studies}

The absorption maximum of the diluted sera was $460 \mathrm{~m} \mu \pm 1 \mathrm{~m} \mu$ in 18 of the 20 patients. One of the patient's sera exhibited its absorption maxima at $465 \mathrm{~m} \mu$ (Figure 2) and another at $470 \mathrm{~m} \mu$. If the human sera were diluted in $0.1 \mathrm{M} \mathrm{PO}_{4}$ buffer, $\mathrm{pH} 7.4$, the spectral curve of the sera was shifted slightly toward higher wave lengths in the 400 to 500 range, and the absorption peak was usually shifted from $460 \mathrm{~m} \mu$ to $462 \mathrm{~m} \mu$, without change in extinction at the respective maxima.

The addition of either salicylate or sulfonamides to icteric serum samples produced alterations in their absorption spectrum. Illustrative changes are presented in Figures 1 and 2. The insert of Figure 1 illustrates the loss of optical density found in the diluted serum after each addition of sulfisoxazole and salicylate until 3 and $5 \mu \mathrm{M}$ had been added, respectively. The spectral curves shown above the insert are the curves of the serum samples after the addition of equal volumes ( 0.2 ml.) of water, $400 \mathrm{mg}$. per cent sulfisoxazole and $400 \mathrm{mg}$. per cent salicylate had been made to either the control or experimental samples in the cuvettes. These volumes corresponded to the $3 \mu \mathrm{M}$ and the $5 \mu \mathrm{M}$ anion additions. As can be seen from these spectral curves, the anions produced a depression in the absorption at $460 \mathrm{~m} \mu$ and a simultaneous increase in absorption over the control sample from 410 to $440 \mathrm{~m} \mu$ with a peak at $420 \mathrm{~m} \mu$. The bilirubin concentration in each of the three cuvette samples, after the spectral analysis was done, gave the same values by the van den Bergh reaction.

The addition of salicylate and sulfisoxazole as illustrated in Figure 1 has now been done on sera from 20 icteric babies and similar changes have been observed in all instances. The percentage loss in absorption at the $460 \mathrm{~m} \mu$ maximum has differed from baby to baby. The range has varied

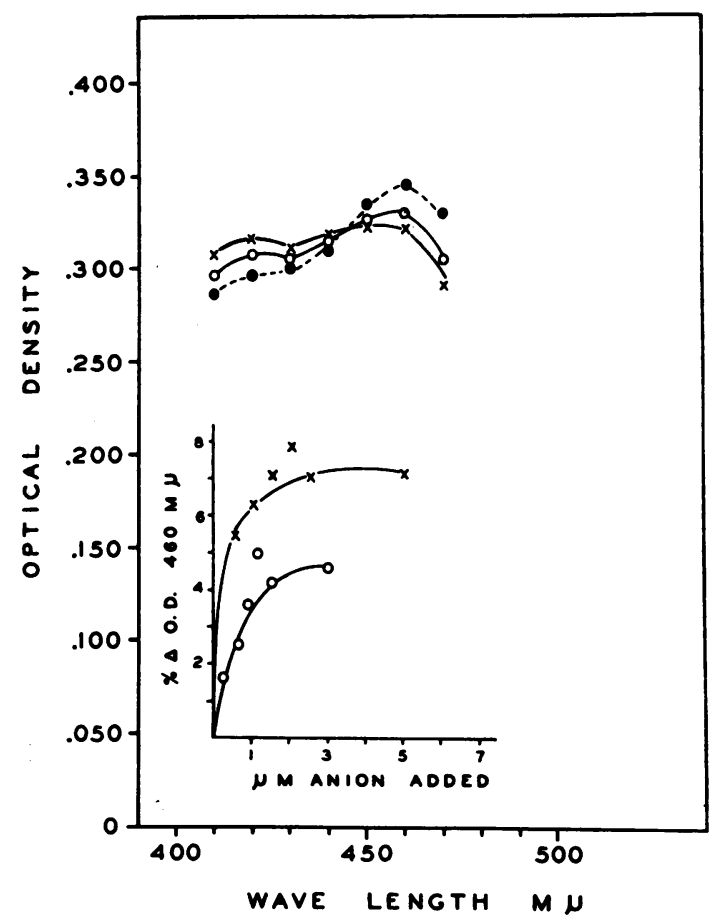

Fig. 1. Spectral Absorption Changes in Serum from a Patient with Erythroblastosis

Bilirubin concentration: 0.4 direct, $12 \mathrm{mg}$. per cent total. The insert is a plot of the loss in optical density at $460 \mathrm{~m} \mu$ after each $20 \lambda$ addition of $400 \mathrm{mg}$. per cent salicylate and sulfisoxazole.

The spectral curves above represent the optical densities of the 1:20 dilution of the serum after the final water or anion additions. Total volume of addition, $\mathbf{0 . 2}$ $\mathrm{ml}$; ; bilirubin concentration in cuvettes, $0.01 \mu \mathrm{M}$ per $\mathrm{ml}$. $---\bullet$, control sample; $\mathrm{O}-\mathrm{O}$, sample containing $3 \mu \mathrm{M}$ sulfisoxazole (final concentration, $1.1 \mu \mathrm{M}$ per $\mathrm{ml}$ ); $\times \longrightarrow \times$, sample containing $5 \mu \mathrm{M}$ sodium salicylate (final concentration, $1.8 \mu \mathrm{M}$ per $\mathrm{ml}$.).

Molar ratios of added anion to bilirubin may be estimated by multiplying $\mu \mathrm{M}$ of anion added (abscissa) by 0.4

bilirubin concentration ( $\mu \mathrm{M}$ per $\mathrm{ml}$.)

from 5 to 12 per cent with $5 \mu \mathrm{M}$ additions of salicylate and 2 to 8 per cent for $3 \mu \mathrm{M}$ additions of sulfisoxazole. Salicylate always produced a greater loss in absorption than the sulfonamide in the sera from the 20 babies studied.

Figure 2 shows the spectral cuves of a serum in which one of three $0.2 \mathrm{ml}$. aliquots was diluted 50 fold with water alone or water and $400 \mathrm{mg}$. per cent sodium salicylate to have final salicylate concentrations of 0.4 and $40.0 \mathrm{mg}$. per cent. The depression of absorption at $465 \mathrm{~m} \mu$ and the appearance of a shoulder at 420 to $440 \mathrm{~m} \mu$ is apparent. 


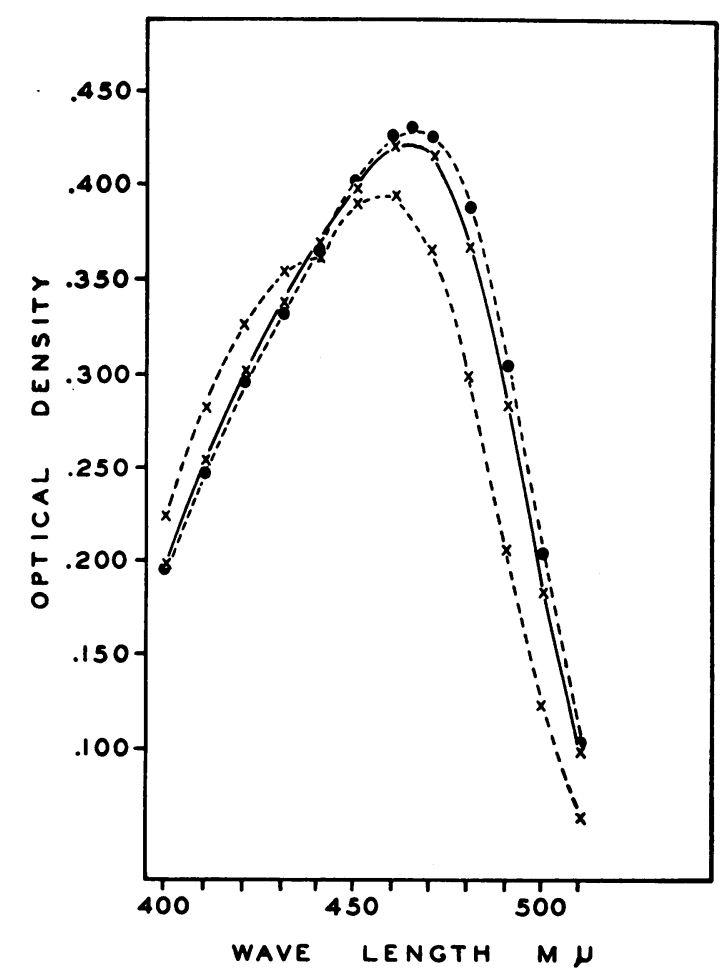

Fig. 2. Spectral Absorption of Serum from a Term INFANT WITH ERYThRoblastosis

Bilirubin concentration: direct 1.9, total $22 \mathrm{mg}$. per cent. -- - $1: 50$ dilution of sera with water ; $\times-\times$, $1: 50$ dilution of sera with water containing sodium salicylate; final concentration, $0.025 \mu \mathrm{M}$ per $\mathrm{ml}$. Per cent $\Delta$ O.D. $465=1.9 ; \times---X, 1: 50$ dilution of sera with water containing sodium salicylate; final concentration, 2.5 $\mu \mathrm{M}$ per ml. Per cent $\Delta$ O.D. $465=10.7$. Concentration of bilirubin in the diluted samples, $0.0076 \mu \mathrm{M}$ per $\mathrm{ml}$.

Also noted as a result of the salicylate was that the depression at 465 was not equaled by an increase in absorption at $420 \mathrm{~m} \mu$, and the whole spectral absorption was progressively shifted to lower wave lengths with higher salicylate concentrations. These two types of experiments have been done using sulfanilic acid and sodium sulfadiazine and qualitatively similar changes as described above have occurred. However much higher molar concentrations were required particularly with sulfadiazine. It is important to add that when adding sulfanilic acid to icteric sera, buffering to prevent a fall in $\mathrm{pH}$ was required. If the $\mathrm{pH}$ of the sample fell below $\mathrm{pH} 7.4$, large losses in absorption all through the 400 to $500 \mathrm{~m} \mu$ range occurred with absorption greater at $450 \mathrm{~m} \mu$ than at $460 \mathrm{~m} \mu$, and the total bilirubin concentration was reduced when measured by the van den Bergh reaction. This latter change was equally well produced by simply lowering the $\mathrm{pH}$ of the serum sample with addition of hydrochloric acid.

Addition of heparin, sodium glucuronate or glucuronic acid to concentrations of $200 \mathrm{mg}$. per cent did not alter the spectral absorption of human sera between 400 to $500 \mathrm{~m} \mu$ provided a fall of $\mathrm{pH}$ was prevented by using $0.1 \mathrm{M}$ phosphate buffer as the diluent.

The absorption of the solutions in the 420 to 440 $\mathrm{m} \mu$ ranges was unstable. If the serum samples after the anion addition were allowed to stand, the absorption at 420 to 440 became progressively diminished, and the total bilirubin was less when measured by the van den Bergh reaction.

To determine whether the spectrophotometric

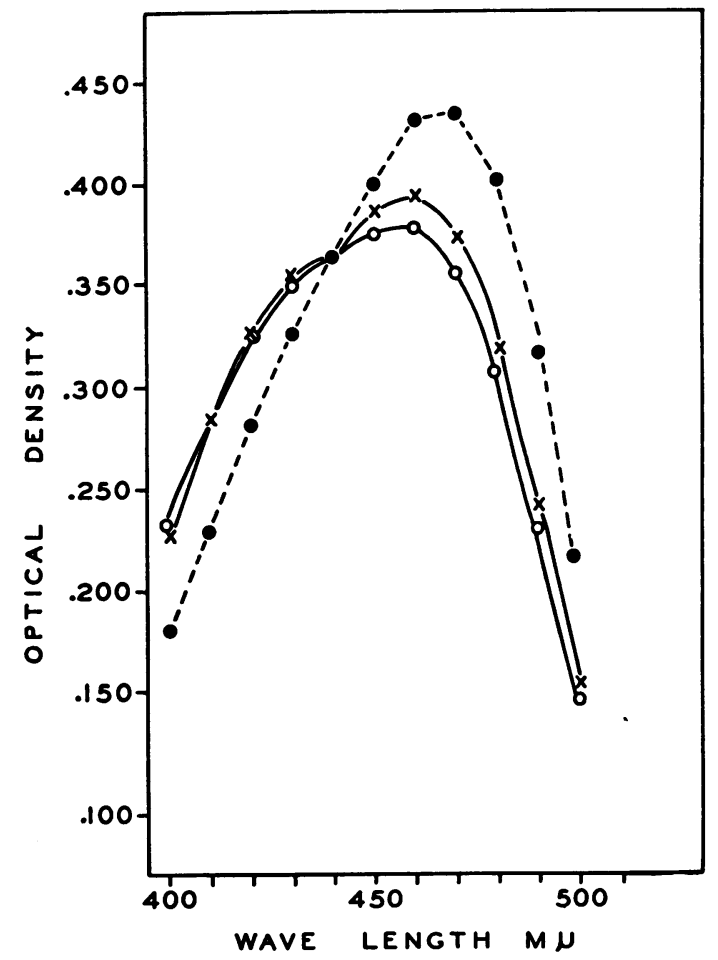

Fig. 3. Spectral Absorptions of Model Serum of Bovine Albumin Bilirubin Solution in $\mathrm{PO}_{4}$ Buffer, PH 7.4

Albumin concentration, $60 \mathrm{mg}$. per cent $(0.009 \mu \mathrm{M}$ per $\mathrm{ml}$.) and bilirubin concentration, $0.55 \mathrm{mg}$. per cent $(0.010$ $\mu \mathrm{M}$ per ml.) were the same in each solution. model serum alone; $O-O$, model serum containing 13 mg. per cent sulfisoxazole $(0.48 \mu \mathrm{M}$ per ml.). Per cent $\Delta$ O.D. $470=18.1$. $\times \longrightarrow \times$, model serum containing $13 \mathrm{mg}$. per cent salicylate $(0.81 \mu \mathrm{M}$ per $\mathrm{ml}$.). Per cent $\Delta$ O.D. $470=15.4$. 
alteration of protein-bound bilirubin in serum caused by organic anions could be explained by changes in binding by serum albumin (or by some other protein fraction), the model serum employing bovine albumin to which bilirubin was added was studied under similar circumstances.

In Figure 3 is illustrated the absorption of model serum using bovine albumin, and it can be seen that the organic anions produced similar effects (compare Figures 2 and 3). However, sulfisoxazole had a relatively greater effect than salicylate on the model bovine serum than occurred with the human serum. Also the absorption maximum of bilirubin bound to bovine albumin was $470 \mathrm{~m} \mu$, not $460 \mathrm{~m} \mu$. It was seen in the experiments employing model sera as in human sera that although increases in concentration of organic anion produced continued loss of absorption at 460 and $470 \mathrm{~m} \mu$, the increases at $420 \mathrm{~m} \mu$ were not of similar magnitudes and a shift in the whole spectral curve to shorter wave lengths occurred (see Figures 2 and 3 ).

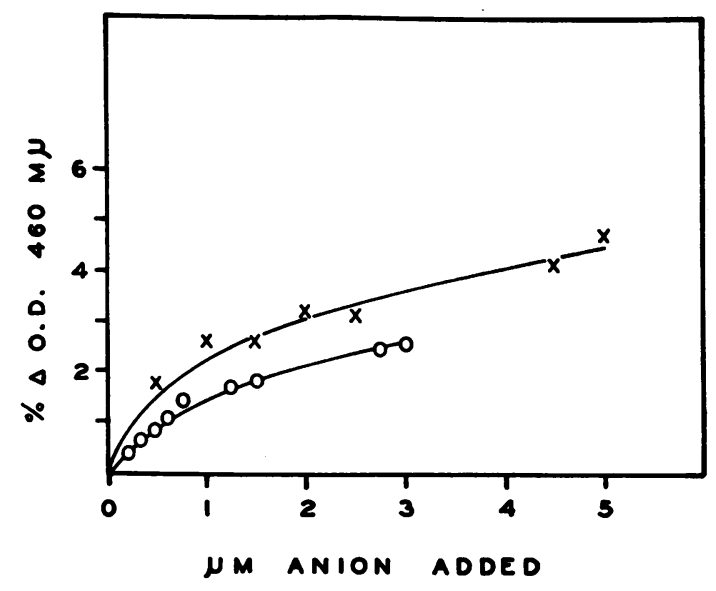

Fig. 4. Spectral Absorption Changes of Crystalline Human Albumin Bilirubin Solution in PO, Buffer, pH 7.4, After Anion Additions

Albumin concentration, $120 \mathrm{mg}$. per cent $(0.017 \mu \mathrm{M}$ per ml.) ; bilirubin concentration, $1.0 \mathrm{mg}$. per cent $(0.018$ $\mu \mathrm{M}$ per ml.). $\times-X$, aqueous $400 \mathrm{mg}$. per cent sodium salicylate added in $20 \lambda(0.5 \mu \mathrm{M})$ amounts; $\mathrm{O}-\mathrm{O}$, aqueous $400 \mathrm{mg}$. per cent sulfisoxazole diethanolamine added in $20 \lambda(0.3 \mu \mathrm{M})$ amounts. Each point represents the difference in optical density between a control sample and the sample to which the anion had been added.

Molar ratios of added anion to bilirubin may be estimated by multiplying $\mu \mathrm{M}$ of anion added (abscissa) by 0.4

$\overline{\text { bilirubin concentration ( } \mu \mathrm{M} \text { per } \mathrm{ml} .)}$

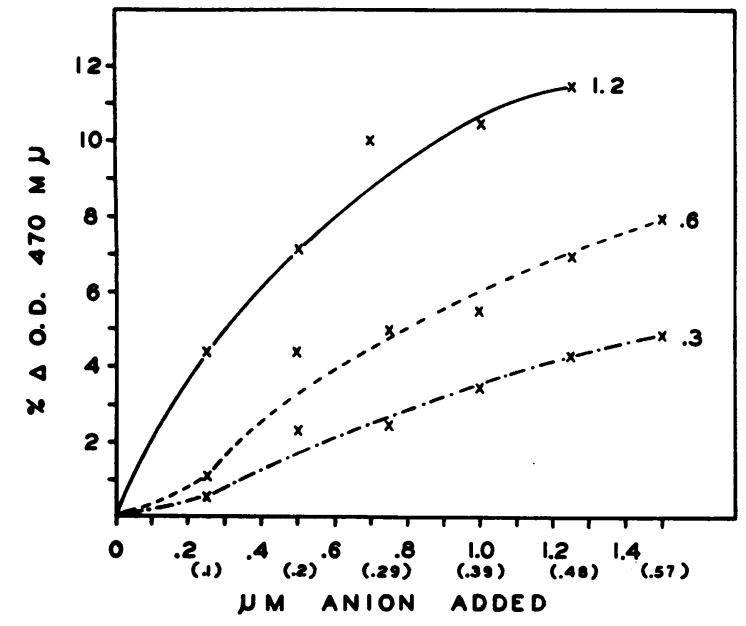

Fig. 5. Bovine Albumin Bilirubin Mixture in PO, BUFFER, PH 7.4.

Each curve represents the per cent difference in optical density between a control sample and the sample to which aqueous $200 \mathrm{mg}$. per cent sodium salicylate had been added in the molar amounts indicated on the abscissa. The numbers in parentheses are the concentrations of the salicylate in $\mu \mathrm{M}$ per $\mathrm{ml}$. in the cuvette samples after each addition. The numbers to the right of each curve are the molar ratio of bilirubin to albumin.

Starting concentrations: $\times-\times$, albumin, $48 \mathrm{mg}$. per cent $(0.008 \mu \mathrm{M}$ per ml.); bilirubin, $0.52 \mathrm{mg}$. per cent $(0.009 \mu \mathrm{M}$ per ml.) ; $\times---X$, albumin, $120 \mathrm{mg}$. per cent ( $0.017 \mu \mathrm{M}$ per ml.); bilirubin, $0.64 \mathrm{mg}$. per cent $(0.010$ $\mu \mathrm{M}$ per ml.) ; $\times-\longrightarrow \times$, albumin, $240 \mathrm{mg}$. per cent $(0.035$ $\mu \mathrm{M}$ per ml.) ; bilirubin, $0.64 \mathrm{mg}$. per cent $(0.010 \mu \mathrm{M}$ per ml.).

Molar ratios of added anion to bilirubin may be estimated by multiplying $\mu \mathrm{M}$ of anion added (abscissa) by 0.4

bilirubin concentration ( $\mu \mathrm{M}$ per ml.)

A single experiment done in duplicate using crystalline human albumin from Cohn fraction $\mathrm{V}^{3}$ was also performed. Solutions of this sample of human albumin and bilirubin had an absorption maximum at $460 \mathrm{~m} \mu$. The extinction coefficient at $460 \mathrm{~m} \mu$ was $4.6 \times 10^{4}$, similar to that at $470 \mathrm{~m} \mu$ of comparable solutions of bovine albumin and bilirubin. The response of this solution to additions of salicylate and sulfisoxazole is illustrated in Figure 4. As with patient's sera, salicylate caused a larger depression in absorption at $460 \mathrm{~m} \mu$ than sulfisoxazole. Considerably more organic anion was required with the crystalline human albuminbilirubin solutions to produce significant alteration

\footnotetext{
${ }^{3}$ Made available through the courtesy of Dr. Morris
} Rosenfeld. 


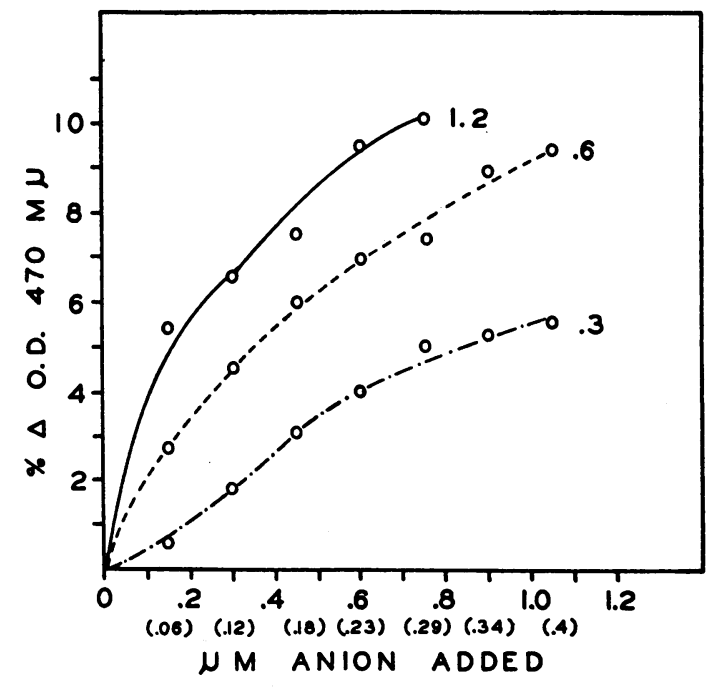

Fig. 6. Bovine Albumin Bilirubin Mixture in PO, Buffer, pH 7.4, to Which Aqueous 200 mg. Per Cent Sulfisoxazole Had Been Added

The conditions of this experiment were identical to those shown in Figure 5.

Molar ratios of added anion to bilirubin may be estimated by multiplying $\mu \mathrm{M}$ of anion added (abscissa) by 0.4

$\overline{\text { bilirubin concentration ( } \mu \mathrm{M} \text { per } \mathrm{ml} .)}$.

of the absorption at $460 \mathrm{~m} \mu$, than was necessary with either the patient's sera (Figures 1 and 7 ) or the bovine-albumin-bilirubin mixtures at comparable albumin concentrations (see Figures 5 and 6.)

In order to elucidate some of the variables which influence the spectroscopic behavior of proteinbound bilirubin, the following studies were done and are illustrated in Figures 4 through 7.

A series of buffered albumin and bilirubin solutions were mixed so as to have different molar concentration ratios of bilirubin to albumin. Three $2.5 \mathrm{ml}$. samples from each molar mixture were pipetted into the cuvettes and $0.02 \mathrm{ml}$. additions of $200 \mathrm{mg}$. per cent salicylate (Figure 5) or sulfisoxazole (Figure 6) were made directly to the cuvette. The absorption at $470 \mathrm{~m} \mu$ was measured after mixing of each addition of anion and compared to the control sample which was equally diluted with distilled water. Figures 5 and 6 show the decrease in optical density (expressed as percentage change from the control sample) plotted against the moles of added anion. The numbers in parentheses refer to the molar concentration of anion in the cuvette.
The results of these experiments indicated $a$ ) that a greater depression of absorption at $470 \mathrm{~m} \mu$ per mole of anion added occurred in the solutions with higher molar ratios of bilirubin to albumin regardless of absolute bilirubin concentration; the curves of the 0.6 and 0.3 molar ratios had the same bilirubin concentration; and $b$ ) that a greater depression of absorption at $470 \mathrm{~m} \mu$ was produced by increasing the anion concentration relative to that of bilirubin and albumin at all molar ratios; the change was not linear.

Figure 7 illustrates the changes in spectral absorption of serum, from a patient who had hyperbilirubinemia, upon additions of sulfisoxazole and salicylate. The molar concentration ratio of bilirubin to protein was constant, but because the serum was diluted $1: 20$ and $1: 50$ the relative concentration of anion to bilirubin and protein dif-

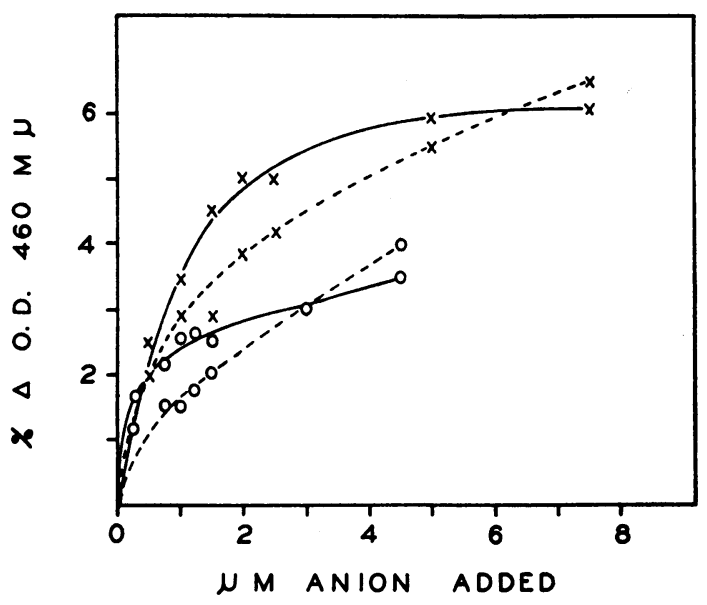

Fig. 7. The Spectral Absorption Changes of Human Serum After Addition of Organic Anion

The undiluted serum had a bilirubin concentration: 0.8 direct, $15 \mathrm{mg}$. per cent total.

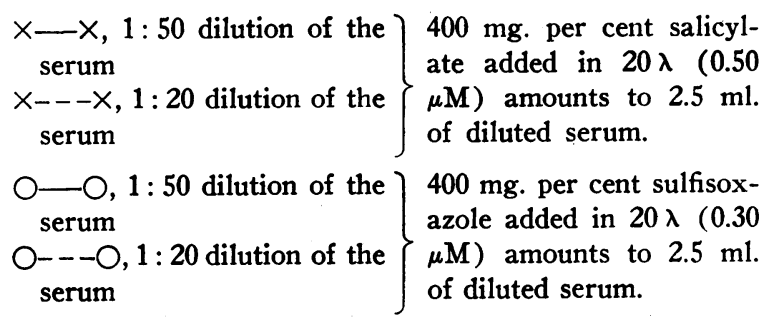

Bilirubin concentration in $1: 20$ dilution, $0.01 \mu \mathrm{M}$ per ml.; in $1: 50$ dilution, $0.005 \mu \mathrm{M}$ per $\mathrm{ml}$.

Molar ratios of added anion to bilirubin may be estimated by multiplying $\mu \mathrm{M}$ of anion added (abscissa) by 0.4

bilirubin concentration ( $\mu \mathrm{M}$ per $\mathrm{ml}.)^{\circ}$ 
fered. It was seen, as with the model serum, that increasing the anion concentration of either salicylate or sulfisoxazole relative to the protein and bilirubin concentrations produced greater depressions in absorption. The importance of absolute as well as relative concentrations of anion, protein and bilirubin was illustrated by the fact that the curves for the $1: 20$ dilutions intersected those of the $1: 50$ dilutions with different slopes. Although not illustrated in Figures 5 and 6, all three curves eventually intersected one another and plateaued at about the same level.

\section{Ultrafiltration studies}

In order to ascertain that the depression in absorption at $460 \mathrm{~m} \mu$ was due to an uncoupling of protein-bound bilirubin, the diluted human or bovine sera were ultrafiltered by centrifugation in 15 instances. The protein-free ultrafiltrates were colored yellow when salicylate, sulfadiazine, sulfisoxazole or sulfanilic acid had been added prior to ultrafiltration. Serum concentrations over 30 $\mathrm{mg}$. per cent of sulfadiazine were required as compared with concentrations of 5 to $25 \mathrm{mg}$. per cent of the other anions. Spectrophotometric analysis of the filtrates showed an absorption maximum at $420 \mathrm{~m} \mu$. After addition of methyl alcohol and diazotized sulfanilic acid the absorption maximum at 420 was absent and a new peak at 530 to 560 $\mathrm{m} \mu$ was present, the absorption peak of bilirubin coupled to diazotized sulfanilic acid. The shift in absorption maximum did not occur when diazotized sulfanilic acid alone was added, but the solutions became colorless, so that it was necessary to add methyl alcohol before addition of the diazo reagent. The control samples of sera ultrafiltered simultaneously had completely colorless filtrates and yielded no colored product by the van den Bergh test. Samples of sera to which glucuronic acid or sodium glucuronate had been added also had colorless filtrates when ultrafiltered and a negative van den Bergh test.

\section{Dialysis studies}

Representative results of a few dialysis experiments are shown in Table I. The sera were diluted as indicated and the anion added. An aliquot was taken and examined spectrophotometrically for the per cent $\Delta$ O.D. $460 \mathrm{~m} \mu$ and the remainder was dialyzed.

It should be pointed out that the methodology of these two approaches are not comparable. In the spectrophotometric procedure, the uncoupled bilirubin competes with the added anion for protein binding, whereas in the dialyses the concentrations of free bilirubin and anion are lowered because they can be dialyzed from the protein phase.

The first three experiments demonstrated a greater loss in bilirubin by dialysis than the spec-

TABLE I

Effect of anions on protein-binding of bilirubin

\begin{tabular}{|c|c|c|c|c|c|c|c|}
\hline \multirow[b]{2}{*}{$\begin{array}{l}\text { Bilirubin } \\
\text { concentration } \\
\text { in original } \\
\text { serum }\end{array}$} & \multirow[b]{2}{*}{$\begin{array}{l}\text { Dilution } \\
\text { of sera for } \\
\text { dialysis }\end{array}$} & \multirow[b]{2}{*}{$\begin{array}{l}\text { Duration } \\
\text { of dialysis }\end{array}$} & \multirow[b]{2}{*}{ Anion added } & \multirow[b]{2}{*}{$\begin{array}{l}\text { Concentration } \\
\text { in diluted } \\
\text { sera of } \\
\text { anion after } \\
\text { addition }\end{array}$} & \multirow[b]{2}{*}{$\begin{array}{l}\text { Bilirubin } \\
\text { concentra- } \\
\text { tion after } \\
\text { dialysis }\end{array}$} & \multicolumn{2}{|c|}{$\begin{array}{l}\text { Per cent change from } \\
\text { control sample }\end{array}$} \\
\hline & & & & & & $\begin{array}{l}\text { Of bilirubin } \\
\text { lost by } \\
\text { dialysis }\end{array}$ & $\begin{array}{l}\text { Of optical } \\
\text { density at } \\
460 \mathrm{m \mu} \text { by } \\
\text { spectropho- } \\
\text { tometry }\end{array}$ \\
\hline $\begin{array}{c}m g . \% \\
1: 15\end{array}$ & $0.5: 0.52$ & $\begin{array}{c}\text { hours } \\
72\end{array}$ & $\begin{array}{c}0 \\
\text { Sulfisoxazole }\end{array}$ & $\begin{array}{c}m g . \% \\
0 \\
15\end{array}$ & $\begin{array}{c}m g . \% \\
8.2 \\
6.9\end{array}$ & -15.8 & -4.3 \\
\hline $0.6: 12.5$ & $0.5: 1.5$ & 10 & $\begin{array}{c}0 \\
\text { Sulfisoxazole }\end{array}$ & $\begin{array}{l}0 \\
3.6\end{array}$ & $\begin{array}{l}12.0 \\
11.4\end{array}$ & -5.0 & -2.4 \\
\hline $0.8: 11$ & $0.2: 10$ & 5 & \begin{tabular}{l}
\multicolumn{1}{c}{0} \\
Sulfisoxazole \\
Salicylate
\end{tabular} & $\begin{array}{l}0 \\
7.8 \\
7.8\end{array}$ & $\begin{array}{r}10.2 \\
9.6 \\
9.4\end{array}$ & $\begin{array}{l}-5.9 \\
-7.8\end{array}$ & $\begin{array}{l}-1.2 \\
-4.7\end{array}$ \\
\hline $1.2: 21$ & $0.2: 10$ & 6 & \begin{tabular}{l}
\multicolumn{1}{c}{0} \\
Sulfisoxazole \\
Salicylate
\end{tabular} & $\begin{array}{l}0 \\
0.8 \\
0.8\end{array}$ & $\begin{array}{l}17.0 \\
17.0 \\
16.0\end{array}$ & $\begin{array}{l}0 \\
-\quad 5.9\end{array}$ & $\begin{array}{l}-3.9 \\
-5.8\end{array}$ \\
\hline
\end{tabular}


trophotometric measurement indicated. The last two experiments demonstrated that the relative effectiveness of salicylate was greater than sulfisoxazole.

After the dialyses the remaining solutions were also tested for salicylate with ferric chloride and for sulfonamide by the Bratton-Marshall technique (34). Both anions were absent at the end of the dialyses.

\section{DISCUSSION}

The spectrophotometric studies demonstrated that protein-bound bilirubin can be modified by organic anions. The new peak which appeared at 420 to $440 \mathrm{~m} \mu$ (the absorption maximum for free bilirubin) after addition of the anion is consistent with uncoupling of bilirubin from protein. The presence of bilirubin in the ultrafiltrates of serum after the anion additions confirmed this interpretation. The reaction of the ultrafiltrates was characteristic of bilirubin rather than its glucuronide, because in aqueous acid solutions it did not couple with the diazo reagent unless alcohol was first added.

The dialysis studies also demonstrated a greater loss of bilirubin in the presence of certain organic anions. Although the bilirubin was not recovered, it was presumed to have been dialyzed from the protein phase after being uncoupled.

Some authors have found that aqueous bilirubin has an absorption peak at $440 \mathrm{~m} \mu(15,19)$ while others found the peak at $420 \mathrm{~m} \mu(35,36)$. The author has found both values. Freshly made aqueous bilirubin had an absorption maximum at $440 \mathrm{~m} \mu$, but on standing, even when protected from light, the peak shifted to $430 \mathrm{~m} \mu$ and finally to $420 \mathrm{~m} \mu$. This shift occurred without much change in the extinction coefficient or change in bilirubin concentration by the van den Bergh reaction (37). No studies were done to investigate these differences in absorption maxima of free bilirubin, but may represent formation of molecular aggregates (38). Mesobilirubin has a spectral curve and diazo reaction very similar to bilirubin's and can be formed by reduction of bilirubin with vigorous heating over metal amalgams (39). Occurrence of such a reduction seemed unlikely.

Even though protein-bound and free bilirubin have similar molecular extinction coefficients, the uncoupling of protein-bound bilirubin as meas- ured by loss of absorption at $460 \mathrm{~m} \mu$ did not produce a quantitative increase at 420 to $440 \mathrm{~m} \mu$. Bilirubin is very insoluble and unstable in aqueous solution at $\mathrm{pH} 7.4$ and may precipitate or oxidize to other derivatives when uncoupled. The progressive loss of absorption in the 420 to $440 \mathrm{~m} \mu$ range of the serum samples containing added anion upon standing or on exposure to light was consistent with the instability of bilirubin, as was the absolute loss of bilirubin when measured by the van den Bergh reaction. Consequently, the quantitative mathematical evaluation for uncoupling as described by Klotz, Triwush and Walker (40) could not be applied. Also the amount of bilirubin uncoupled when expressed as percentage change of optical density was really a minimum value because the absorption of the free bilirubin contributed progressively more to the total absorption at $460 \mathrm{~m} \mu$ as more anion was added. If the total spectral curves of Figure 2 could be resolved into the individual curves for free and protein-bound bilirubin, the curve of free bilirubin with $40 \mathrm{mg}$. per cent salicylate would include a greater area in the $460 \mathrm{~m} \mu$ range than the free bilirubin curve containing $4 \mathrm{mg}$. per cent salicylate. Despite these drawbacks, the spectrophotometric studies did show qualitative similarity to the chemical laws of mass action of competition of two ions for the same locus. This was exemplified by the response of protein-bound bilirubin at different molar ratios to similar anion concentrations, and also when the bilirubin protein ratio was small, low concentrations of anion did not interfere with the protein bound bilirubin.

Both salicylate and sulfonamides have affinities for albumin through their acid radicals and compete with other organic anions for protein binding $(40,41)$. The major binding sites involved are the acid radicals of anions and the cationic amine groups of albumin, primarily the $\epsilon$-amino groups of lysine (27). If the carboxyl groups of the proprionic acid side chains of bilirubin are concerned in the protein binding, then interference by salicylates or sulfonamides might be expected. Other groups in the bilirubin molecule may also be involved in its protein binding (42). The finding (19) that guanidination of albumin reduced its bilirubin binding capacity also indicated that more than the proprionic side chains are involved, for Klotz and Urquhart (43) found that the binding 
of methyl orange was unaffected by guanidination of albumin. Because of their relatively simpler structure and greater solubility in aqueous media, one would expect that considerably greater molar concentrations of sulfonamides and salicylate relative to bilirubin would be required to interfere significantly with the protein binding of bilirubin. However, in the present studies the concentrations of salicylate and sulfisoxazole used were within the limits of blood levels seen in clinical medicine. The serum protein and bilirubin concentrations were chosen in the present studies at a level which might be present in interstitial fluid particularly of brain.

In view of the protein binding of bilirubin, it is of interest that Rosenfeld and Surgenor found that when using hematin for albumin determinations, bilirubin did not interfere (28). This suggests that if hematin is bound by the same loci as bilirubin its binding constant might be considerably greater than that of bilirubin. However, the sera Rosenfeld and Surgenor used contained mostly direct reacting bilirubin and a different type of binding has been suggested for bilirubin glucuronide (26). The author has recent spectrophotometric data showing that salicylate and sulfonamides behave toward albumin-bound hematin just as they do toward bilirubin bound to albumin, and in vitro, hematin and bilirubin interfere with one another for protein binding (37).

The clinical pertinence of the findings in this report is to re-emphasize that many organic ions are bound to serum albumin and may compete with one another. The data presented and the studies of Brown, Zuelzer and Robinson (44) demonstrate that the serum bilirubin concentration does not necessarily reflect the diffusible or total body bilirubin.

Although a value for a dissociation constant (or constants) of protein-bound bilirubin is not exactly known, its value is obviously small. Hence, a small absolute increase in diffusible bilirubin would represent a very large percentage change. Therefore, uncoupling of protein-bound bilirubin by organic anions would produce a large relative change in the diffusible bilirubin. This increase could shift the diffusion gradient of bilirubin and promote its diffusion out of extracellular fluids into cell cytoplasm. Administered sulfisoxazole, by its interference with protein binding of bilirubin, may prevent accumulation of bilirubin in serum thus forcing it to remain unbound or loosely bound to other tissue proteins in relatively higher concentrations in extravascular phases of body fluids. This would promote greater opportunity for filtration and diffusion through cell membranes. If the bilirubin cannot concentrate in the vascular space attached to serum proteins, the plasma bilirubin concentration will be low and will become relatively misleading in the management of hyperbilirubinemia in the neonate. The reports of kernicterus in premature infants given sulfisoxazole who had low serum bilirubins fit this concept (11, 12). Also, the reports $(8,9)$ of infants with high heme pigment concentrations with neurologic signs of early kernicterus and relatively low serum bilirubin levels are consistent with methemalbumin interfering with the bilirubin concentrating on serum proteins. In premature babies larger absolute amounts of bilirubin may occur in the extravascular body fluids without being reflected by high serum levels, because premature infants have lower serum albumin concentrations than full term infants (45) and, therefore, their plasma would become saturated at lower bilirubin concentrations.

The additional information of the relative saturation of serum proteins with bilirubin is also desirable. A technique such as that reported in the present studies could be applied where the amount of organic anion necessary to uncouple proteinbound bilirubin would be a measure of the relative saturation of serum proteins and, indirectly, a measure of diffusible bilirubin. This type of determination, coupled with a knowledge of the total albumin concentration, may give a more precise approach to the therapy of hyperbilirubinemia and explain some of the exceptions to the concept that prevention of kernicterus depends upon keeping the serum bilirubin below a concentration of 18 to $20 \mathrm{mg}$. per cent during the first 72 hours of life.

The fact that salicylate is rarely used in the neonate has been fortunate. Many infants have received sulfadiazine, but the concentrations, as found in the present study, which were required to interfere with protein binding of bilirubin in vitro, were considerably higher than those probably obtained clinically and consequently would not enhance the development of kernicterus. 


\section{SUMMARY}

The protein binding of bilirubin has been studied by spectrophotometry, ultrafiltration and dialysis. It was demonstrated that the organic anions, salicylate and sulfisoxazole, could uncouple protein-bound bilirubin and thereby allow its passage through semipermeable membranes free from protein. The concentrations of anion necessary to produce this effect were within the ranges observed in clinical medicine. Sulfadiazine and sulfanilic acid were also capable of displacing protein-bound bilirubin but required higher molar concentrations. The displacement of the protein-bound bilirubin in the presence of different anion concentrations was observed to show qualitative similarities to the chemical laws of mass action of two anions competing for a common locus on the albumin molecule.

The importance of variations in protein binding and of diffusible rather than total bilirubin was emphasized in the pathogenesis of kernicterus.

\section{REFERENCES}

1. Zimmerman, H. M., and Yannet, H. Kernikterus, jaundice of the nuclear masses of the brain. Amer. J. Dis. Child. 1933, 45, 740.

2. Mollison, P. L., and Cutbush, M. Haemolytic disease of the newborn; criteria of severity. Brit. med. J. 1949, 1, 123.

3. Hsia, D. Y., Allen, F. H., Jr., Gellis, S. S., and Diamond, L. K. Erythroblastosis fetalis. VII. Studies of serum bilirubin in relation to kernicterus. New Engl. J. Med. 1952, 247, 668.

4. Claireaux, A. E., Cole, P. G., and Lathe, G. H. Icterus of brain in newborn. Lancet 1953, ii, 1226.

5. Waters, W. J., Richert, D. A., and Rawson, H. H. Bilirubin encephalopathy. Pediatrics 1954, 13, 319.

6. Day, R. L. Inhibition of brain respiration in vitro by bilirubin. Reversal of inhibition by various means. Proc. Soc. exp. Biol. (N. Y.) 1954, 85, 261.

7. Zetterström, R., and Ernster, L. Bilirubin, an uncoupler of oxidative phosphorylation in isolated mitochondria. Nature 1956, 178, 1335.

8. Abelson, N. M., and Boggs, T. R., Jr. Plasma pigments in erythroblastosis fetalis. I. Spectrophotometric absorption patterns. Pediatrics 1956, 17, 452.

9. Tuttle, A. H. Serum pigment studies in newborn infants. I. Erythroblastosis fetalis. J. Dis. Child. 1955, 89, 544.

10. Crosse, V. M., Meyer, T. C., and Gerrard, J. W. Kernicterus and prematurity. Arch. Dis. Child. 1955, 30, 501.
11. Silverman, W. A., Andersen, D. H., Blanc, W. A., and Crozier, D. N. A difference in mortality rate and incidence of kernicterus among premature infants allotted to two prophylactic antibacterial regimens. Pediatrics 1956, 18, 614.

12. Harris, R. C., Lucey, J. F., and MacLean, J. R. Kernicterus in premature infants associated with low concentrations of bilirubin in the plasma. Pediatrics 1958, 21, 875.

13. Johnson, L. M. Consciousness and the chemical environment of the brain. Report of the Twenty-Fifth Ross Pediatrics Research Conference, March, 1957, 100.

14. Cohn, E. J. The chemical specificity of the interaction of diverse human plasma proteins. Blood 1948, 3, 471.

15. Najjar, V. A., and Childs, B. Crystallization and properties of serum bilirubin. J. biol. Chem. 1953, 204, 359.

16. Gray, C. H., and Kekwick, R. A. Bilirubin-serum protein complexes and the van den Bergh reaction. Nature 1948, 161, 274.

17. Klatskin, G., and Bungards, L. Bilirubin-protein linkages in serum and their relationship to the van den Bergh reaction. J. clin. Invest. 1956, 35, 537.

18. Bourrillon, R. Isolement et propriétés du complexe bilirubine-sérum albumine du sérum. Bull. Soc. Chim. biol. (Paris) 1957, 39, 385.

19. Martin, N. H. Preparation and properties of serum and plasma proteins. XXI. Interactions with bilirubin. J. Amer. chem. Soc. 1949, 71, 1230.

20. Pedersen, K. O., and Waldenström, J. Studien über das Bilirubin in Blut und Galle mit Hilfe von Elektrophorese und Ultrazentrifugierung. HoppeSeyler's Z. physiol. Chem. 1937, 245, 152.

21. Forrai, E., and Sivo, R. Physikalisch-chemische Eigenschaften des Bilirubins in Körperflüssigkeiten. Biochem. Z. 1927, 189, 162.

22. Gregory, R. L., and Andersch, M. The filterability of bilirubin in obstructive jaundice. J. Lab. clin. Med. 1937, 22, 1111.

23. Snapper, I., and Bendien, W. M. On the physicochemical condition of the bilirubin in the blood serum and urine. Acta med. scand. 1938, 98, 77.

24. Coolidge, T. B. Chemistry of the van den Bergh reaction. J. biol. Chem. 1940, 132, 119.

25. Barac, G. Interactions of bilirubin with plasma proteins, and the state of bilirubin in normal human plasma. Arch. int. Physiol. 1953, 61, 129.

26. Childs, B. The nature of direct bilirubin. Bull. Johns Hopk. Hosp. 1955, 97, 333.

27. Klotz, I. M. Protein interactions in The Proteins, Vol. I B, H. Neurath and K. Bailey, Eds. New York, Academic Press Inc., 1953, p. 727.

28. Rosenfeld, M., and Surgenor, D. M. The hematinbinding reaction as a basis for serum albumin determination. J. biol. Chem. 1953, 199, 911.

29. Westphal, U., and Gedigk, P. Azorubin-binding capacity of normal and pathological sera. Proc. Soc. exp. Biol. (N. Y.) 1951, 76, 838. 
30. Rutstein, D. D., Ingenito, E. F., and Reynolds, W. E. The determination of albumin in human blood plasma and serum; a method based on the interaction of albumin with an anionic dye-2-(4'hydroxybenzeneazo) benzoic acid. J. clin. Invest. 1954, 33, 211.

31. Blondheim, S. H. The relation between the albumin concentration of serum and its dye-binding capacity. J. Lab. clin. Med. 1955, 45, 740.

32. Odell, G. B. In vitro studies of the effect of sulfonamids on bilirubin (abstract). A.M.A. Amer. J. Dis. Child. 1958, 96, 535.

33. Malloy, H. T., and Evelyn, K. A. The determination of bilirubin with the photoelectric colorimeter. J. biol. Chem. 1937, 119, 481.

34. Bratton, A. C., and Marshall, E. K., Jr. A new coupling component for sulfanilamide determination. J. biol. Chem. 1939, 128, 537.

35. With, T. K. Spectral absorption of bilirubin. Measurements in pure aqueous solutions and in solutions containing human serum. Acta physiol. scand. 1945, 10, 172.

36. Cremer, R. J., Perryman, P. W., and Richards, D. H. Influence of light on the hyperbilirubinaemia of infants. Lancet 1958, i, 1094.

37. Odell, G. B. Unpublished observations.

38. Jirsa, M., and Sedláček, B. Aggregation of bilirubin in some solvent-precipitant systems. Chem. Listy
1956, 50, 520. (Cited from Chem. Abstr. 1956, 50, 11403 h.)

39. Heilmeyer, L. Spectrophotometry in Medicine. London, A. Higler, Ltd., 1943, p. 163.

40. Klotz, I. M., Triwush, H., and Walker, F. M. The binding of organic ions by proteins. Competition phenomena and denaturation effects. J. Amer. chem. Soc. 1948, 70, 2935.

41. Davis, B. D. The binding of sulfonamide drugs by plasma proteins. A factor in determining the distribution of drugs in the body. J. clin. Invest. 1943, 22, 753.

42. With, T. K. The behavior of the bilirubin-albumin bond in serum on diazotization. Scand. J. clin. Lab. Invest. 1958, 10, 188.

43. Klotz, I. M., and Urquhart, J. M. The binding of organic ions by proteins. Comparison of native and of modified proteins. J. Amer. chem. Soc. 1949, 71, 1597.

44. Brown, A. K., Zuelzer, W. W., and Robinson, A. R. Studies in hyperbilirubinemia. 2. Clearance of bilirubin from plasma and extravascular space in newborn infants during exchange transfusion. A. M. A. Amer. J. Dis. Child. 1957, 93, 274.

45. Darrow, D. C., and Cary, M. K. The serum albumin and globulin of newborn, premature and normal infants. J. Pediat. 1933, 3, 573. 